TECHNICAL TRANSACTIONS 12/2019

CIVIL ENGINEERING

DOI: $10.4467 / 2353737$ XCT.19.132.11498

SUBMISSION OF THE FINAL VERSION: 15/12/2019

\author{
Waldemar Parkitny (D) orcid.org/0000-0003-2653-0985 \\ wpark@usk.pk.edu.pl \\ Chair of Transportation Systems, Civil Engineering Faculty, Cracow University of Technology
}

\title{
PAID CAR PARK ZONE MANAGEMENT WITH REGARD TO THE PRINCIPLES OF PROVIDING PARKING SPACES FOR DISABLED PEOPLE
}

ZARZĄDZANIE STREFAMI PŁATNEGO PARKOWANIA W ASPEKCIE ZASAD UDOSTĘPNIANIA MIEJSC PARKINGOWYCH DLA OSÓB NIEPEŁNOSPRAWNYCH

\begin{abstract}
Disability can cover various areas of people's activities, but it is primarily associated with difficulties that relate to independent movement. The possibility of free movement is one of the basic human rights. People with disabilities who cannot get to work and take employment, despite a desire to do so, assimilate with the rest of society to a worse extent, do not have the means to support themselves and do not earn national income. From this point of view, programs and activities aimed at maximising mobility and access to various types of places for people with disabilities, including those in public space, are very important. These types of places include paid parking zones in cities. Their location in city centres provides access to most offices. Due to the fact that they are located in public space, municipalities and city authorities have an impact on their management and on establishing the principles of their functioning. A very important element of this management is determining the rules for providing parking spaces in paid parking zones, particularly with regard to the amount of parking fees for disabled people. The article provides an analysis of the management of the provision of disabled parking spaces in relation to paid parking zones in all voivodeship cities in Poland.
\end{abstract}

Keywords: paid parking zone, car park, disabled people, transport, management, law, transport accessibility, mobility, spatial management

\section{Streszczenie}

Niepełnosprawność może obejmować różne obszary ludzkiej aktywności, jednak kojarzy się przede wszystkim z utrudnieniami, które dotyczą samodzielnego poruszania się. Możliwość swobodnego przemieszczania się jest jednym z podstawowych praw człowieka. Osoby niepełnosprawne, które nie mogą dotrzeć do pracy i jej podjąć, pomimo tego, że chcą, gorzej asymilują się z pozostałą częścią społeczeństwa, nie mają środków na własne utrzymanie i nie wypracowują dochodu narodowego. Dlatego też ważne są programy i działania zmierzające do maksymalizacji mobilności i dostępności do różnego rodzaju miejsc dla osób niepełnosprawnych. Tego typu miejscami są między innymi strefy płatnego parkowania w miastach. Ich położenie w centrach miast zapewnia dostęp do większości instytucji. Bardzo ważnym elementem tego zarządzania jest określenie zasad udostępniania miejsc parkingowych w strefach płatnego parkowania, w tym w szczególności wysokości opłat za parkowanie pojazdów osób niepełnosprawnych. W artykule dokonano takiej analizy w stosunku do stref płatnego parkowania we wszystkich miastach wojewódzkich w Polsce.

Slowa kluczowe: strefa płatnego parkowania, parking, osoby niepełnosprawne, transport, zarządzanie, prawo, dostępność transportowa, mobilność, gospodarka przestrzenna 


\section{Introduction}

Koźmiński, Jemielniak [1] list the following functions that make up the management:

1. planning,

2. organisation,

3. information and knowledge management,

4. the organisation's financial management,

5. operations management,

6. personnel policy,

7. marketing and public relations,

8. negotiations,

9. control.

All of the above functions comprise activities relating to the designation, organisation and functioning of paid parking zones in the city. These activities are often complicated, and their effect is the need to compromise between the expectations of city-centre residents who, to provide space for their cars, are increasingly demanding the inclusion of individual districts in the paid parking zones, and the demands of drivers from peripheral districts, drivers from neighbouring cities and tourists who are interested in direct access to the city centre. In addition, due to the high dynamics of the increase in the number of cars, previously undertaken actions should be corrected from time to time, regarding, for example, the boundaries of paid parking zones, the number of spaces, traffic organisation, parking prices. This causes chaos, confusion and upset for drivers. This results in extreme demands formulated by some decision makers regarding paid parking zones from those which assume their liquidation, to the postulates aimed at covering the entire cities with the paid parking zone. An example of such an idea is the idea of introducing a paid parking zone in the entire city of Krakow.

Very often, paid parking zones generate large revenues for cities from parking fees. The effect of the fees is to be, inter alia: the reduction of vehicular traffic, the reduction of vehicular traffic congestion, less pollution of the natural environment by exhaust gases, change in drivers' habits. However, it should be remembered that the policy of reducing the accessibility of city centres to motor vehicles may have negative effects. One of these effects is the reduction of available access to city centres for groups of people who especially need this access. This includes people with disabilities, who are often forced to use cars for access to medical facilities, offices, workplaces, schools, universities, shops, etc. These institutions are usually located in city centres, so where paid parking zones are being introduced. The goal of managing paid parking zones in this case is to ensure an adequate number of spaces for disabled people, to designate and mark them, and to develop rules for accessing and using paid parking spaces in the zones. This approach is consistent with the concept of the company as an entity that meets the needs of the environment [2]. In the case of a paid parking zone, the enterprise will be an external company or a relevant department in the city hall managing the zone. 


\section{Definitions of disabled people}

In the literature, there are various definitions regarding people with disabilities and the resulting different methods for estimating their number. Antczak, Grabowska, Polańska [3] list the biological, functional and social characteristics of disability models.

The biological model considers disability, which defines disability as "any loss of performance or abnormality in the psychological, physical or anatomical structure or functioning of the body, and the psychosocial consequences of this absence or disability" (WHO definition).

The functional model defines:

1. disability as "any limitation or impossibility to lead an active life in a way or to the extent considered to be typical of a person of a similar age and the same sex" (WHO definition).

2. impediment as "limitation or impossibility of full implementation of social roles corresponding to age, gender and compatible with social and cultural conditions" (WHO definition).

The social aspect takes into account "the lack or limitation of human activity caused by contemporary social organisation, which does not take into account the needs of people with physical damage and learning difficulties, thereby excluding them from the mainstream of social life”.

It follows from the above definitions that disability can cover various areas of human activity. In the colloquial meaning, however, it is primarily associated with difficulties that relate to independent movement. The possibility of free movement is one of the basic human rights. Lack of this possibility hinders or prevents people from functioning in society. It is an obstacle to professional work. People with disabilities who cannot get to work and take employment, despite a desire to do so, assimilate with the rest of society to a worse extent, do not have the means to support themselves and do not earn national income. From this point of view, programs and activities aimed at maximising mobility and access to various types of places for people with disabilities, including those in public space, are very important. These types of places include paid parking zones in cities. Their location in city centres provides access to most offices, schools, colleges, shops, service outlets, cultural facilities etc. Due to the fact that they are located in public space, municipalities and city authorities have an impact on their management and on establishing the principles of their functioning. A very important element of this management is determining the rules for providing parking spaces in paid parking zones, particularly with regard to the amount of parking fees, as well as the total number of parking spaces and designated parking spaces intended only for disabled people. 


\section{The scale of the problem}

When considering adapting paid parking zones to the needs of disabled people, it is important to estimate the number of people in this category with regard to particular management aspects concerning parking payment rules and the number of separate parking spaces for disabled people. Determining the exact number of disabled people in Poland causes some difficulties. In addition to the various definitions of disability mentioned above, the different methodologies for testing the number of people with disabilities are also a source of great difficulty.

According to the National Census performed in 2011, there were around 4,697,000 legally and biologically disabled people in Poland. Legally disabled are people whose disability has been confirmed by Zakład Ubezpieczeń Społecznych (Social Insurance Institution) or disability adjudication teams. This number was smaller than the data from 2002 (around $5,456,700$ people) and greater than the results obtained in 1988 (around 3,735,500 people).

EHIS research, the purpose of which is to monitor the health status of the population of the European Union, was conducted in Poland in 2014. The tested sample consisted of over 12,000 households (i.e. around 29,000 people). These studies indicate that there are around 4,905,100 people with legal and biological disabilities. Even more interesting is the data referring to the number of people with disabilities aged 15 and over, i.e. at an age that roughly coincides with the age at which a driving license can be obtained. In the case of Poland, the number is around 5,805,100 people with disabilities out of a total of around $32,719,500$ people within that age range in 2012 . This constitutes as much as $17.7 \%$ of the population [3].

\section{Literature review and adopted research method}

There are relatively few publications in the literature on the mobility of disabled people, especially the availability of parking space, not only in terms of infrastructure, but also with regard to legal regulations, parking prices and the organisation of paid parking zones.

Safety, mobility and transport of the elderly and disabled were the subject of the Transed conference [4].

General rules for using paid parking zones in major Polish cities were presented by Parkitny [5], while another article [6] described the issue of parking integration with the municipal public transport system. A further paper [7] presents an analysis of parking parameters in terms of infrastructure.

Taylor and Józefowicz [8] draw attention to the method of choosing places of recreation for disabled people. These are places that, among other things, do not require significant financial outlay and are accessible to people with disabilities. Therefore, both criteria should be taken into account in the development of regulations and the construction of paid parking zones discussed below in this article. These authors also studied the mobility of disabled people in urban space [9-11]. 
The authors van der Waerden, de Bruin and da Silva [12] presented the preferences of drivers in terms of additional services in parking lots, which may also be relevant for disabled people. Car parks, paid parking zone equipment and drivers' preferences are also discussed [13].

Carvalho and Paiva [14] drew attention to the problem of illegal parking in places for disabled people. They developed a device that allows identification of vehicles parking illegally in parking spaces for disabled people by means of cameras smartphones and software and informs appropriate persons.

One of the useful tools for parking search can be the system described in the article by Tsai, Kiong and Sinn [15]. They proposed the system to which functions one can number: recommendation and reservation, outdoor navigation to the car park, parking lot detection, and car park indoor navigation.

In the article authored by Ogórek, Kulig and Przeniczny [16] an analysis of the adaptation of buses, stops and the organisation of urban transport to the needs of the disabled and the elderly was performed. The analysis concerns sixteen cities in Małopolska.

Parkitny in a thesis [17] presented the aspect of using a parking lot located in a paid parking zone depending on the weather; furthermore, the modelling of parking lot selection was described in another article [18].

The research presented in this article was based on the analysis of resolutions and documents of the authorities of all voivodeship cities in Poland which concern paid parking zones as well as statistical data of individual municipal units managing these zones.

\section{Analysis of the rules for using the paid parking zones by disabled people}

The above definitions of disability from the point of view of a driver - a disabled person who wants to park in one of the provincial cities in Poland - are not as important as his disability certificate, which is the basis for issuing a so-called parking card and the rules for using parking spaces. These rules are different in different cities. They are described by city councils or municipal councils, and depend on the preferences of individual councils. Below are the parking rules for paid parking zones in all provincial cities in Poland.

\subsection{Rules for using parking cards in Poland}

Entrance to the paid parking zone is marked with sign D-44 (paid parking zone). Fees should be paid for parking the vehicle in designated places on public roads. Parking on the pavement is possible if: it does not impede pedestrians(i.e. if a free space of at least $1.5 \mathrm{~m}$ is left); there is no parking prohibition nearby and the weight of the car does not exceed 2.5 tons.

The Act of 20.06.1997 Road Traffic Law [19] defines road signs that do not have to be followed by disabled people who have the right to drive motor vehicles, and drivers who transport disabled people, provided that they take special care. These signs are: no traffic in both directions (B-1); no motor vehicle, except for two-wheel motorcycles 
(B-3); no bus (B-3a); no motorbikes (B-4); no entry of mopeds (B-10); no parking (B-35); no parking on odd days (B-37); no parking on even days (B-38); restricted parking (B-39) [20, 21].

The document that confirms the rights of disabled people to not comply with selected road signs and to use so-called "envelopes" (i.e. parking space intended for disabled people and parking spaces marked with a wheelchair symbol on a blue background) is a parking card. Without the need to adjudicate again (i.e. based on an existing judgment), such a document can be obtained by persons who:

1. have a certificate of severe disability with the following symbols:

a) 04-O - persons with diseases of the organs of eyesight;

b) $05-\mathrm{R}$ - persons with mobility impairment;

c) $10-\mathrm{N}$ - neurological diseases;

2. 2have an indication of qualifying for a parking card.

To obtain a parking card, the following must be submitted in person:

1. 1an application in the administrative district team for declaring disability;

2. a photograph;

3. confirmation of payment of a fee of $21 \mathrm{PLN}$ for a parking card;

4. declaration of having the right to parental responsibility, guardianship or wardship in the case of persons under 18 years of age or incapacitated persons.

An additional advantage of the parking card is the possibility of its use not only in Poland, but also in other European Union countries; however, as a rule, it does not exempt (except for the cases mentioned above) payment of the parking fee.

Parking cards can also be obtained by institutions that deal with rehabilitation and the care and education of people with disabilities who have limited mobility on their own $[21,22]$.

The condition for using free parking is to display the parking card in the windscreen of the vehicle in such a way that it is legible to the controllers of the paid parking zone. This is emphasised by the regulations of the paid parking zones of the cities analysed below.

\subsection{Rules for using exemptions from parking fees and subscriptions in provincial cities in Poland}

Below are described the rules of selling subscriptions for disabled persons, which authorise parking in all paid parking zones in particular provincial cities in Poland (Table 1).

Table 1. Rules for using exemptions from parking fees and subscriptions in provincial cities

\begin{tabular}{|l|l|}
\hline \multicolumn{1}{|c|}{ Operating hours of the zone } & Rules for using exemptions from parking fees and \\
subscriptions
\end{tabular}




\begin{tabular}{|c|c|}
\hline \multicolumn{2}{|c|}{ Bydgoszcz } \\
\hline $\begin{array}{l}\text { Parking fees apply between } 8.00 \text { and } 17.00 \text { from } \\
\text { Monday to Friday. Fees do not apply on public } \\
\text { holidays. }\end{array}$ & $\begin{array}{l}\text { In Bydgoszcz, disabled people who have a parking card } \\
\text { can park for free in a so-called "envelope", i.e. a place for } \\
\text { a disabled person's vehicle. In other places, it is possible } \\
\text { if at the same time, the disabled person has a so-called } \\
\text { disabled person identifier. This identifier can be obtained } \\
\text { by persons who: } \\
\text { 1. submitted an appropriate application to Zarząd Dróg } \\
\text { Miejskich i Komunikacji Publicznej w Bydgoszczy } \\
\text { (Municipal Roads and Public Transport Board in } \\
\text { Bydgoszcz); } \\
\text { 2. have a disabled person's parking card which was } \\
\text { issued on the basis of a certificate of severe disability } \\
\text { with the code 05-R or 10-N or equivalent, or legal } \\
\text { guardians of a disabled person with a parking card, } \\
\text { who is a co-owner or owner of the vehicle "whose } \\
\text { ownership is confirmed by an entry in the registration } \\
\text { certificate or being the user of the vehicle under } \\
\text { a civil law agreement concluded in writing with the } \\
\text { signatures of the parties to the contact certified by } \\
\text { a notary public" [23]. } \\
\text { The application should be accompanied by photocopies } \\
\text { of: vehicle registration card, parking card, disability } \\
\text { certificate, civil law agreement and child's birth certificate } \\
\text { (in the case of guardians of disabled minors). } \\
\text { Vehicles from, among others, institutions that deal with } \\
\text { the rehabilitation, care and education of people with } \\
\text { disabilities are exempted from fees (a parking card for this } \\
\text { institution and a disabled person's ID are required) [23]. }\end{array}$ \\
\hline \multicolumn{2}{|r|}{ Gdańsk } \\
\hline $\begin{array}{l}\text { The rules related to the hours when the parking fee } \\
\text { applies in the paid parking zone in Gdańsk vary } \\
\text { depending on the district and are among the most } \\
\text { complicated in the country. In general, the parking } \\
\text { fee is not charged on Saturdays, Sundays and } \\
\text { public holidays, which according to the regulations } \\
\text { fall from Monday to Friday. } \\
\text { In the case of parking in the Old Town } \\
\text { (Śródmieście) and Wrzeszcz, parking is payable } \\
\text { between } 9.00 \text {-17.00, from Monday to Friday. } \\
\text { People who want to park in the Main Town sector } \\
\text { and in May } 3 \text { Street, must pay to do so from } \\
\text { Monday to Friday from } 9.00 \text { to } 20.00 \text {, and in } \\
\text { Aniołki, Oliwa and Przymorze sectors on the same } \\
\text { days, but from } 9.00 \text { to } 15.00 \text {. During the summer } \\
\text { holidays, i.e. from July } 1 \text { to August } 31 \text {, parking in } \\
\text { Jelitkowo between } 9.00-17.00 \text {, from Monday to } \\
\text { Friday is also payable. }\end{array}$ & $\begin{array}{l}\text { As in other cities, people with disabilities do not pay for } \\
\text { parking in spaces for disabled people if they have } \\
\text { a parking card. } \\
\text { In order to not pay for parking in all places in the paid } \\
\text { parking zone, an individual must have the ID "N"+. The } \\
\text { ID is issued free of charge. It is obligatory in the following } \\
\text { districts: Śródmieście, Wrzeszcz, Aniołki, Przymorze, } \\
\text { Oliwa, Jelitkowo. To obtain it, an application must } \\
\text { submitted including photocopies of: } \\
\text { 1. registration evidence; } \\
\text { 2. legal title to the vehicle; } \\
\text { 3. driving license; } \\
\text { 4. medical certificate confirming the absence of } \\
\text { contraindications for driving; } \\
\text { 5. certificate of a significant degree of locomotive organ } \\
\text { disability or neurological diseases, and fulfillment of } \\
\text { the conditions that allow the issuing of the parking card } \\
\text { described above [24]. }\end{array}$ \\
\hline
\end{tabular}




\begin{tabular}{|c|c|}
\hline \multicolumn{2}{|c|}{ Gorzów Wielkopolski } \\
\hline $\begin{array}{l}\text { Paid parking in the paid parking zone takes place } \\
\text { from } 9.00 \text { to } 18.00 \text { from Monday to Friday. }\end{array}$ & $\begin{array}{l}\text { The number of parking spaces in Gorzów Wielkopolski } \\
\text { is } 941 . \text { Disabled people can park free of charge only in } \\
\text { designated places in the zone for them, i.e. in so-called } \\
\text { "envelopes". To avoid being charged, drivers must have } \\
\text { a parking card. }\end{array}$ \\
\hline \multicolumn{2}{|r|}{ Katowice } \\
\hline $\begin{array}{l}\text { The collection of parking fees in the paid parking } \\
\text { zone in Katowice is valid from } 9.00-16.30 \text { on } \\
\text { business days, from Monday to Friday [25]. }\end{array}$ & $\begin{array}{l}\text { The zero rate for parking disabled persons' vehicles } \\
\text { applies for drivers with a parking card. }\end{array}$ \\
\hline \multicolumn{2}{|r|}{ Kielce } \\
\hline $\begin{array}{l}\text { In Kielce, parking in the paid parking zone is } \\
\text { charged. Charges apply from Monday to Friday, } \\
\text { from } 9.00 \text { to } 17.00 \text {. }\end{array}$ & $\begin{array}{l}\text { People with disabilities can purchase an ID type "I" } \\
\text { for } 10 \text { PLN per year. It entitles the driver to free and } \\
\text { unlimited parking time throughout the zone [26]. }\end{array}$ \\
\hline \multicolumn{2}{|r|}{ Krakow } \\
\hline $\begin{array}{l}\text { The paid parking zone in Krakow is one of the } \\
\text { largest in Poland. This is the first city in Poland } \\
\text { where from 22.09.2019 fees have also been } \\
\text { charged on Saturdays. Currently, paid parking } \\
\text { applies on business days from Monday to Saturday } \\
\text { from } 10.00 \text { to } 20.00 \text {. }\end{array}$ & $\begin{array}{l}\text { Changing a parking place from one subzone to another } \\
\text { makes it necessary to pay another parking fee in the new } \\
\text { subzone, even if the time limit for parking in the previous } \\
\text { subzone has not yet expired. } \\
\text { The fee for a "N" subscription is } 2.50 \text { PLN for } 1 \text { month } \\
\text { [27]. Until 2017, those who had received a certificate } \\
\text { of severe or moderate disability were entitled to } \\
\text { purchase a subscription. Currently, the purchase of } \\
\text { such a subscription is possible for people who have } \\
\text { a valid parking card for a disabled person. A parking } \\
\text { card is only granted to people who have significantly } \\
\text { reduced mobility, and is not granted to those who only } \\
\text { have reduced mobility. Such persons must purchase } \\
\text { a subscription for } 250 \text { PLN [28]. }\end{array}$ \\
\hline \multicolumn{2}{|r|}{ Lublin } \\
\hline $\begin{array}{l}\text { In Lublin, as in other voivodeship cities, the } \\
\text { parking fee is required from Monday to Friday } \\
\text { from } 8.00 \text { to } 17.00 .\end{array}$ & $\begin{array}{l}\text { A subscription "N" is provided for the disabled. It is valid } \\
\text { throughout the entire area, except for private car parks. } \\
\text { The subscription price is } 4 \text { PLN/month. It is valid for no } \\
\text { more than } 18 \text { months. [29] }\end{array}$ \\
\hline \multicolumn{2}{|r|}{ Łódź } \\
\hline $\begin{array}{l}\text { The zone is payable on business days, from } \\
\text { Monday to Friday from } 8.00 \text { to } 18.00 \text {. }\end{array}$ & $\begin{array}{l}\text { People with severe or moderate disabilities and in } \\
\text { possession of a parking card can receive a subscription with } \\
\text { zero fees. It authorises parking in the entire zone. [30] }\end{array}$ \\
\hline \multicolumn{2}{|r|}{ Olsztyn } \\
\hline $\begin{array}{l}\text { The regulations of the paid parking zone in Olsztyn } \\
\text { state that the fees in this zone apply from Monday to } \\
\text { Thursday, on business days between } 8.00-16.00 \text {, and } \\
\text { on Fridays between } 8.00-15.00 \text { [31]. }\end{array}$ & $\begin{array}{l}\text { According to the regulations of the paid parking zone } \\
\text { in Olsztyn, disabled people and drivers transporting } \\
\text { disabled people do not have to pay for parking if they have } \\
\text { a parking card. }\end{array}$ \\
\hline
\end{tabular}




\begin{tabular}{|c|c|}
\hline \multicolumn{2}{|r|}{ Opole } \\
\hline $\begin{array}{l}\text { Parking in Opole on Saturdays, Sundays and public } \\
\text { holidays is free. Parking is paid between } 8.00 \text { and } \\
17.00 \text { on business days, Monday to Friday. }\end{array}$ & $\begin{array}{l}\text { Resolution XIII/203/15 of the Opole City Council of } \\
\text { 2.07.2015 provides zero parking rates for disabled people } \\
\text { who have parking cards and for people who drive vehicles } \\
\text { and transport disabled people who have such cards [32]. }\end{array}$ \\
\hline \multicolumn{2}{|r|}{ Poznań } \\
\hline $\begin{array}{l}\text { Parking is charged in the Poznań zone for parking } \\
\text { a vehicle from Monday to Friday from } 8.00 \text { to } \\
18.00 \text {. }\end{array}$ & $\begin{array}{l}\text { In Poznań, the monthly fee for a vehicle transporting } \\
\text { a disabled person registered for permanent or temporary } \\
\text { residence in the Wielkopolskie Voivodeship is } 5 \text { PLN. } \\
\text { The minimum period for which an ID can be bought } \\
\text { is } 3 \text { months, and the maximum is } 12 \text { months. The } \\
\text { required documents are: vehicle registration card, } \\
\text { identity document confirming the place of residence in } \\
\text { the Wielkopolskie Voivodeship, parking card, civil law } \\
\text { agreement indicating the actual user of the vehicle in the } \\
\text { case of, for example, leasing [33]. }\end{array}$ \\
\hline \multicolumn{2}{|r|}{ Rzeszów } \\
\hline $\begin{array}{l}\text { Of all the Polish voivodeship cities, Rzeszów has } \\
\text { introduced a paid parking zone most recently. This } \\
\text { occurred on 01.01.2016. Paid parking in Rzeszów } \\
\text { applies from Monday to Friday, on working days, } \\
\text { between } 9.00 \text { and } 17.00 \text {. }\end{array}$ & $\begin{array}{l}\text { The number of places in the zone is } 2,239 \text {. It is the } \\
\text { largest zone in the Podkarpackie Voivodeship. Disabled } \\
\text { people who want to park in the zone can buy a monthly } \\
\text { subscription. The subscription price is } 1 \text { PLN [34], [35]. }\end{array}$ \\
\hline \multicolumn{2}{|r|}{ Szczecin } \\
\hline $\begin{array}{l}\text { Drivers wanting to park in the paid parking zone } \\
\text { in Szczecin must pay if they park from Monday to } \\
\text { Friday, between } 8.00 \text { and } 17.00 \text {. Free parking is } \\
\text { possible on May 2, December } 24 \text { and } 31 \text { and on } \\
\text { public holidays. }\end{array}$ & $\begin{array}{l}\text { Zero parking fee is provided for: } \\
\text { 1. persons with disabilities with a significant degree of } \\
\text { disability who have a parking card; } \\
\text { 2. parents and legal guardians of disabled persons up to } \\
\text { the age of } 18 \text { who are disabled or who own vehicles or } \\
\text { have vehicles based on a loan or leasing agreement - } \\
\text { upon presentation of a parking card, ID card, disability } \\
\text { certificate, vehicle registration card, loan agreement, } \\
\text { leasing if the vehicle is disposed on the basis of such } \\
\text { contracts; } \\
\text { 3. war invalids who are the owners of vehicles - the right } \\
\text { is granted on the basis of a Military Invalid ID card, ID } \\
\text { card, vehicle registration card, loan agreement, leasing if } \\
\text { the vehicle is disposed of under such agreements. } \\
\text { There is also a 12-month flat-rate fee for a disabled } \\
\text { person at the amount of } 10 \text { PLN [36]. }\end{array}$ \\
\hline \multicolumn{2}{|r|}{ Toruń } \\
\hline $\begin{array}{l}\text { In Torun, the paid parking zone is divided into } \\
2 \text { subzones: subzone A is located in the Old } \\
\text { Town, and subzone B on the streets adjacent to } \\
\text { the Old Town. In both subzones, payment is due } \\
\text { for parking from Monday to Friday, on weekends, } \\
\text { from } 8.00 \text { to } 18.00 \text {. }\end{array}$ & $\begin{array}{l}\text { There are no reduced one-time fees for disabled people in } \\
\text { the city, but drivers can buy a subscription for a disabled } \\
\text { person for } 12 \text { PLN. It is valid for } 1 \text { month [37]. }\end{array}$ \\
\hline
\end{tabular}




\begin{tabular}{|c|c|}
\hline \multicolumn{2}{|c|}{ Warsaw } \\
\hline $\begin{array}{l}\text { Paid parking in the paid parking zone in Warsaw is } \\
\text { valid from Monday to Friday, with the exception } \\
\text { of May 2, } 24 \text { and } 31 \text { December, between } 8.00 \text { and } \\
18.00 \text {. }\end{array}$ & $\begin{array}{l}\text { Free parking for people with disabilities, as in other cities, } \\
\text { is allowed in designated parking spaces ("envelopes"). } \\
\text { People who have the "N+" card can park without paying } \\
\text { in the entire paid parking zone. This card is issued } \\
\text { free of charge. It can be obtained by a disabled person } \\
\text { with significant degree of disability or a person whose } \\
\text { disability is confirmed by a disability certificate or } \\
\text { a persons with a degree of disability that causes significant } \\
\text { difficulties in moving independently [38]. }\end{array}$ \\
\hline \multicolumn{2}{|c|}{ Wrocław } \\
\hline $\begin{array}{l}\text { The days when fees apply in the paid parking zone } \\
\text { in Wroclaw are business days from Monday to } \\
\text { Friday from } 9.00 \text { to } 18.00 \text {. }\end{array}$ & $\begin{array}{l}\text { For persons with a certificate of slight disability } \\
\text { connected with neurological diseases (code 10-N) } \\
\text { or musculoskeletal disorders (code } 05-\mathrm{N} \text { ), the N } \\
\text { subscription has been introduced. It is valid in one of } \\
\text { the } 14 \text { subzones in which the business is conducted or } \\
\text { there are workplaces [39]. The price of N subscriptions is } \\
10 \text { PLN for one month, } 50 \text { PLN for half a year, } 100 \text { PLN } \\
\text { for year. } \\
\text { Free "O" identifiers have also been introduced. People } \\
\text { who can use these are: } \\
1 . \text { disabled people, registered in Wroclaw, with reduced } \\
\text { mobility holding a certificate or ID card of a disabled } \\
\text { person with a significant or moderate degree of disability } \\
\text { with a reason from code R or N, } \\
\text { 2. legal representatives or the spouses of these persons } \\
\text { or other persons driving their vehicles and carrying } \\
\text { a disabled person [40]. }\end{array}$ \\
\hline \multicolumn{2}{|c|}{ Zielona Góra } \\
\hline $\begin{array}{l}\text { Paid parking in the paid parking zone applies } \\
\text { between } 9.00 \text { and } 18.00 \text { from Monday to Friday, } \\
\text { on business days. }\end{array}$ & $\begin{array}{l}\text { The zero parking rate applies to persons with a disabled } \\
\text { parking card, people who transport disabled persons } \\
\text { holding such a card, and for marked vehicles that are } \\
\text { structurally designed to transport disabled persons [41]. }\end{array}$ \\
\hline
\end{tabular}

Source: own binding based on data provided in the bibliography

\section{Summary and conclusions}

A parking card is a document enabling parking at designated places in paid parking zones. However, using it is associated with the following inconveniences and problems:

1. a limited number of designated parking spaces in the zone;

2. the need to search for spaces;

3. the lack of information on the occupancy of spaces;

4. the need to submit a complete set of documents, pay a fee for issuing the card and collect it personally. 
Parking in other places in most cities is possible subject to purchasing an additional subscription. Subscription prices vary, but are generally not high. The price of subscription ranges from 1 PLN/1 month in Rzeszów, 10 PLN/12 months in Szczecin up to 12 PLN/1 month in Toruń. Free subscriptions are available in Bydgoszcz, Gdańsk, Łódź and Warsaw. There are different rules for sharing subscriptions in individual cities. Sometimes the procedures associated with obtaining subscriptions are complicated. However, not all cities provide for the possibility of leaving the disabled person's car outside the designated parking spaces ("envelopes"); in such cases, a normal parking fee applies.

A problem for people frequently travelling may also be different hours of parking. Paid parking zones are being introduced to increase the rotation of vehicles in car parks, especially in city centres and during the working hours of offices. From 8.00, charges apply in the paid parking zones of Bydgoszcz, Lublin, Łódź, Olsztyn, Opole, Poznań, Szczecin, Toruń and Warsaw. is the latest time that charges applies to is 20.00; this is the case for the paid parking zones in Krakow. In this city, parking fees are also obligatory on Saturdays.

Parking fees apply for the shortest time in Katowice (7.5 hours). In Gdańsk Główne Miasto, parking fees are compulsory for 11 hours/24 hours. In five cities, the fee for the paid parking zone applies for 10 hours $/ 24$ hours.

General problems for drivers may be the change of zone boundaries occurring in some cities, the liquidation of previously existing parking spaces or street fragments available for parking and emerging proposals for differentiating parking fees in individual subzones. The above actions may lead to an increase in the congestion of vehicle traffic and chaos associated with searching for free parking spaces, the extended time taken searching for a place and unintentional violation of regulations by drivers.

\section{References}

[1] Koźmiński A. K., Jemielniak D., Zarządzanie od podstaw Podręcznik akademicki, Wydawnictwa Akademickie i Profesjonalne, Warszawa 2008.

[2] Suszyński C. (red.), Przedsiebiorstwo, wartość zarządzanie, Polskie Wydawnictwo Ekonomiczne, Warszawa 2007.

[3] Antczak R., Grabowska I., Polańska Z., Podstawy i źródła danych statystyki osób niepetnosprawnych, "Wiadomości Statystyczne", Vol. 2 (681)/2018, 21-43.

[4] Transed 2001. Towards Safety, Independence and Security. 9th International Conference on Mobility and Transport for Elderly and Disabled People, 2-5.07.2001, Warsaw, Poland.

[5] Parkitny W., Analiza zasad korzystania za stref platnego parkowania jako elementu logistyki miejskiej dla wybranych grup użytkowników w największych miastach Polski, „Przedsiębiorczość i Zarządzanie”, T. 17, Z. 12, cz. 2/2016, 390-396, ISSN 1733-2486.

[6] Parkitny W., Oczekiwania osób podróżujących a integracja parkingów z miejskim systemem transportu zbiorowego, „Czasopismo Inżynierii Lądowej, Środowiska i Architektury, Journal of Civil Engineering, Environment and Architecture: JCEEA", t. 33, z. 63, nr 4/2016, 391-406, ISSN 2300-8903. 
[7] Parkitny W., Analiza parametrów parkingów realizowanych przez kolej $w$ południowo-wschodniej Polsce, „Transport Miejski i Regionalny”, Vol. 3/2013, 19-24, ISSN 1732-5153.

[8] Taylor Z., Józefowicz I., Intra-urban daily mobility of disabled people for recreational and leisure purpose, "Journal of Transport Geography”, 24, 2012, Elsevier, 155-172.

[9] Taylor Z., Józefowicz I., Daily mobility of disabled people for healthcare facilities and their accessibility in urban spaces, "Geographia Polonica”, Vol. 85, No. 3, 2012, 5-22.

[10] Taylor Z., Józefowicz I., Geograficzne badania niepetnosprawności ze szczególnym uwzględnieniem codziennej ruchliwości osób niepetnosprawnych w przestrzeni miasta - część I, „Przegląd Geograficzny”, T. 84, z. 2, 2012, 261-278.

[11] Taylor Z., Józefowicz I., Geograficzne badania niepetnosprawności ze szczególnym uwzględnieniem codziennej ruchliwości osób niepetnosprawnych $w$ przestrzeni miasta - część II, „Przegląd Geograficzny”, T. 84, z. 4, 2012.

[12] van der Waerden P., de Bruin M., da Silva A.N.R., Car drivers' knowledge and preferences regarding additional services at parking facilities, World Conference on Transport Research - WCTR 2016 Shanghai. 10-15 July 2016, “Transportation Research Procedia” 25C, 2017, 4053-4061.

[13] Parkitny W., Using the theory of games to modelling the equipment and prices of car parking, "IOP Conference Series: Materials Science and Engineering”, Vol. 245/2017, Session IV: Theories and Methods in Civil Engineering and Architecture, BIM, Mathematical and Statistical Methods, Risk Management, Regional Planning, Sustainable Urban Development, Urban Sociology, Economics and Politics, GIS - Based Modelling and planning, Computer Aided Design, 1-10, ISSN 1757-899X, DOI: 10.1088/1757899X/245/6/062046.

[14] Carvalho C., Paiva S., Potentiate Social Inclusion through Detecting Illegal Parking in Places for Disabled People, International Journal of Information Systems and Social Change, Volume 9, Issue 3, 36-52, July 2018.

[15] Tsai M.-F., Kiong Y. C. i Sinn A., Smart service relying on Internet of Things technology in parking systems, “The Journal of Supercomputing”, Volume 74, Issue 9, 4315-4338, September 2018.

[16] Ogórek P., Kulig M., Przeniczny A., Dostosowanie miejskich systemów transportu publicznego do potrzeb osób z ograniczonymi możliwościami poruszania się, w tym szczególnie osób niepetnosprawnych i osób starszych, „Transport Miejski i Regionalny”, Vol. 5/2019, 14-20.

[17] Parkitny W., Analysis of dependences between using of parking places and chosen parameters of weather on the example of underground parking in Cracow, "IOP Conference Series: Earth and Environmental Science”, Vol. 95/2017, Session IV: Environmental Legislation, Biogeosciences, Geological Heritage \& Geoparks, Geotourism, Economy in Geology, Urban Planning, 1-10, ISSN 1755-1315, DOI: 10.1088/1755-1315/95/5/052011.

[18] Parkitny W., Analysis of chosen logit models to predict the behaviour of personal vehicles' drivers with reference to car parks choice, „Logistyka” Vol. 6/2014, „Logistyka - nauka Artykuły recenzowane” DVD nr 3, 8383-8391, ISSN 1231-5478.

[19] Ustawa z 20.06.1997 r. Prawo o Ruchu Drogowym (Dz. U. z 2005 r. Nr 108, poz. 908 ze zm.). 
[20] https://www.bialystok.pl/pl/dla_mieszkancow/komunikacja_miejska/parkowanie_ w_miescie /osoby-niepelnosprawne-1.html (online: 11.10.2019).

[21] http://mopsbydgoszcz.pl (online: 11.10.2019).

[22] Rozporządzenie Ministra Pracy i Polityki Społecznej z dnia 18 czerwca 2014 r. W sprawie rodzaju placówek uprawnionych do uzyskania karty parkingowej (Dz. U. z 2014 r., poz. 818).

[23] http://www.ZDMIKP.bydgoszcz.pl/pl/strefa-platnego-parkowania (online: 11.10.2019).

[24] https://gzdiz.gda.pl/zalatw-sprawe/parkowanie-osob-niepelnosprawnych,a,3248 (online: 11.10.2019).

[25] Uchwała nr XXX/589/16 Rady Miasta Katowice z dnia 14 września 2016 r. w sprawie ustalenia stref płatnego parkowania dla pojazdów samochodowych na drogach publicznych na obszarze miasta Katowice.

[26] https://www.mzd.kielce.pl (online: 11.10.2019).

[27] Uchwała Nr LXXXIX/2177/17 Rady Miasta Krakowa z dnia 22 listopada 2017 r. w sprawie ustalenia strefy płatnego parkowania, ustalenia opłat za postój pojazdów samochodowych na drogach publicznych w strefie platnego parkowania, wprowadzenia opłaty abonamentowej dla niektórych użytkowników dróg oraz sposobu pobierania tych opłat.

[28] Dybała B., Kraków. Niepetnosprawni cierpia przez... RODO. Wielu może się pożegnać ze zniżkami na parkowanie w: https://gazetakrakowska.pl/krakow-niepelnosprawni-cierpiaprzez-rodo-wielu-moze-sie-pozegnac-ze-znizkami-na-parkowanie/ar/13266784 (online: 11.10.2019).

[29] http://lublin.spp24.pl/dla-osob-niepelnosprawnych (online: 11.10.2019).

[30] http://lodz.spp24.pl/dla-osob-niepelnosprawnych (online: 11.10.2019).

[31] Regulamin Strefy Płatnego Parkowania - Załącznik do Uchwały nr XLIV/853/18 Rady Miasta Olsztyn z dnia 31 stycznia 2018 r. w sprawie ustalenia strefy płatnego parkowania w Olsztynie, zasad jej funkcjonowania oraz wysokości stawek opłat i opłaty dodatkowej oraz sposobu ich pobierania, ze zm. (Dz. Urz. Województwa Warmińsko-Mazurskiego z 2018 r., poz. 924).

[32] Uchwała XIII/203/15 Rady Miasta Opole z dnia 2 lipca 2015 r. w sprawie ustalenia strefy płatnego parkowania, określenia wysokości stawek i sposobu pobierania opłat za postój pojazdów samochodowych na drogach publicznych w strefie płatnego parkowania (Dz. Urz. Woj. Opolskiego z 2015 r. poz. 1698).

[33] http://www.poznan.pl (online: 11.10.2019).

[34] Uchwała Nr XVIII/372/2015 Rady Miasta Rzeszowa z dnia 17 listopada 2015 w sprawie ustanowienia na drogach publicznych miasta Rzeszowa strefy płatnego parkowania pojazdów samochodowych oraz wprowadzenia wysokości opłat za postój pojazdów, wysokości opłaty dodatkowej i sposobu ich poboru.

[35] Uchwała Nr XIX/401/2015 Rady Miasta Rzeszowa z dnia 1 grudnia 2015 zmieniająca uchwałę w sprawie ustanowienia na drogach publicznych miasta Rzeszowa strefy platnego parkowania pojazdów samochodowych oraz wprowadzenia wysokości opłat za postój pojazdów, wysokości opłaty dodatkowej i sposobu ich poboru. 
[36] Uchwała $\mathrm{nr}$ XX/564/12 Rady Miasta Szczecin z dnia 25 czerwca 2012 r. w sprawie ustalenia strefy płatnego parkowania, opłat za parkowanie pojazdów samochodowych na drogach publicznych Miasta Szczecin oraz sposobu ich pobierania.

[37] Załącznik Nr 1 do uchwały nr 640/17 Rady Miasta Torunia z dnia 7 września 2017 r. w sprawie ustalenia strefy płatnego parkowania, opłat za postój pojazdów samochodowych oraz opłat dodatkowych za nieuiszczenie opłat za postój pojazdów samochodowych na drogach publicznych w strefie płatnego parkowania w mieście Toruniu.

[38] Uchwała nr XXXVI/1077/2008 Rady Miasta Stolecznego Warszawy z dnia 26 czerwca 2008 roku w sprawie ustalenia strefy płatnego parkowania, wysokości stawek opłaty za parkowanie pojazdów samochodowych na drogach publicznych w strefie, wysokości opłaty dodatkowej oraz określenia sposobu pobierania tych opłat oraz opłat dodatkowych za nieuiszczenie opłat za postój pojazdów samochodowych na drogach publicznych w strefie płatnego parkowania.

[39] http://www.zdium.wroc.pl/wzory-abonamentow (online: 11.10.2019).

[40] https://www.wrocław.pl (online: 11.10.2019).

[41] Uchwała nr VII.80.2011 Rady Miasta Zielona Góra z dnia 29 marca 2011 r. w sprawie ustalenia Stref Płatnego Parkowania. 